\author{
佐 田富 \\ 道 \\ 雄*1
}

\title{
Review of Studies on Gas-Liquid Two-Phase Flow and Mixture Systems
}

\author{
Michio SADATOMI*2 \\ *2 Department of Mechanical System Engineering, Graduate School of Science and Technology, \\ Kumamoto University, 2-39-1 Kurokami, Kumamoto-shi, Kumamoto, 860-8555 Japan
}

\begin{abstract}
Gas-liquid two-phase flow and mixture systems are encountered in various industrial apparatuses and applications. The systems can be categorized as the following four: (a ) the systems with heat transfer and with the flow of both gas and liquid, like boiling two-phase flow in heat exchangers, (b) the systems without heat transfer but with the flow of both gas and liquid, like adiabatic twophase flow in oil pipe line systems, (c) the systems with heat transfer but without the flow of one of gas and liquid, like pool boiling, and ( $d$ ) the systems without heat transfer and without the flow of one of gas and liquid, like aeration in chemical reaction and water purification systems. Of these, the first two categories are mainly dealt here and the relating papers reported in "Transactions of the Japan Society of Mechanical Engineers, Series B" and in "JSME International Journal, Series B" since January 2004 to August 2006 are reviewed to seek the future studies in the field of the gas-liquid two-phase flow and mixture systems.
\end{abstract}

Key Words: Multiphase Flow, Gas-Liquid Two-Phase Flow, Interfacial Phenomena, Bubble, Liquid Droplet, Liquid Film, Review

\section{1.はじめに}

気液二相流動系と混合系はさまざまな産業上の装置 や応用において見られ，次の四つに分類できる。（1） 熱交換器内の沸騰二相流のように熱移動を伴いかつ気 液両相ともに流動する気液二相流動系，（2)石油パイ プラインのように熱移動を伴わないが気液両相ともに 流動する気液二相流動系，（３）プール沸騰のように熱 移動を伴いかつ片方の相のみが流動する気液の混合 系，（4) 化学反応層や浄水槽内のエアレーションのよ うに熱移動を伴わないが片方の相のみが流動する気液 の混合系，である。この展望では, 2004 年 1 月〜2006 年 8 月までに,「日本機械学会論文集 B 編」と $\lceil J S M E$ International Journal, Series B」に発表され た論文について，上記の 4 分類のうち(1)，(2)の気

\footnotetext{
* 原稿受付 2006 年 10 月 13 日.

*1 正員, 熊本大学大学院自然科学研究科(业860-8555 熊本市 黒髪 2-39-1).

E-mail : sadatomi@mech.kumamoto-u.ac.jp
}

液二相流動系の研究を主としてレビューを行うととも に(3), (4)の気液の混合系の研究動向にも触れて, 両分野での今後の研究課題を探る.

\section{2. 熱移動を伴う気液二相流動系}

単一直管内の流れについては，同心環状流路を用い て原子炉燃料集合体内のスペーサがバーンアウトに及 ぼす影響を調べた実験(1), ヘリカルコイル形の核融合 実験装置に対するダイバータの設計に関連して直径 9 $\mathrm{mm}$ 以下の細管を用いて行われた限界熱流速の実 験(2), 原子炉の圧力容器と炉心溶融物 (デブリ)の凝固 相の間の微小すきまにおける気液対向流制限 (CCFL) 特性を調べた実験 ${ }^{(3)}$, 小形熱交換器におけるマイクロ チャネル内の沸騰気液二相流の薄膜挙動 ${ }^{(4)}$ と熱伝 達(5)(6) や直径 $10 \mathrm{~mm}$ 水平管内の純粋冷媒と混合冷媒 の沸騰二相流の圧力損失と流動様式(7), 短い細管ノズ ルから高温水を噴出する際の自己蒸発による気液二相 噴流特性 ${ }^{(8)}$ を調べた実験がある。さらには，宇宙環境 での高性能冷却を目指した液体へリウム気液二相流の 
数値解析 ${ }^{(9)}$ ならびに潜熱利用ループ式排熱システム の動特性の実験と解析 ${ }^{(10)(11)}$, プレート式熱交換器内 の垂直沸騰流動特性を中性子ラジオグラフィー法で調 ベた実験 ${ }^{(12)}$, 二相閉ループ熱サイフォンでノートパソ コンの CPUを冷却しょうとする実験 ${ }^{(13)}$, 蒸気圧を駆 動源として高所の高温部から低所の低温部へ熱を輸送 するトップヒート形の熱輸送ループの開発に関する実 験 ${ }^{(14)}$ がある.

さらに複雑な断面形状をもつ原子炉燃料集合体内の 沸騰二相流については, 従来形の正方格子燃料体にお ける限界出力 ${ }^{(15)}$, 新形のちゅう密三角格子燃料体にお ける限界出力と圧力損失(16) (18) を調べた実験がある.

以上より, 小形熱交換器におけるマイクロチャネル 等の微細管内の流れに関する研究, 宇宙環境での高性 能冷却を目指した研究, 新形のちゅう密三角格子燃料 体に関する研究が, 最近の研究動向であるように思わ れる。

\section{3. 熱移動を伴わない気液二相流動系}

原子炉燃料集合体内の二相流についてまず述べる. 新形のちゅう密三角格子燃料体に関するものが多く, 圧力損失の実験 ${ }^{(19)}$, スペーサが環状流の液膜挙動に及 ぼす影響を調べた数值解析 ${ }^{(20)}$, サブチャネル間の乱流 混合を調べた実験 ${ }^{(21)}$ がある.そのほか, 正方格子燃 料体における中央サブチャネルと壁面サブチャネルの ボイド率と圧力損失の評価法を調べた研究 ${ }^{(22)}$, 管群を 横切る気泡流の流動特性を PIV 法で調べた実験(23), スペーサが環状流の液膜挙動に及ぼす影響を調べるた めに円管内に模擬スペーサを入れた実験があ る(24)(25).さらに, 原子炉の循環系への応用を目指し た, 鉛ビスマス中の気泡ポンプ(26)やジェットポン プ(27)(28) の実験的研究もある. 原子炉とは直接のかか わりはないが, 気液二相流用のポンプとして, 遠心ポ ンプ(29)や二重反転形軸流ポンプ(30) の実験的研究も行 われている。

二相流の気液分離については, 沸騰水形原子炉用の 旋回羽根を使う遠心分離形(31) と壁面のぬれ性を低下 させた $\mathrm{Y}$ 継手を使う方法(32) がそれぞれ実験的に研究 されている.さらに継手などの特異点(singularity) での流れについては, 急拡大部におけるボイド率と流 動様式の変化 ${ }^{(33)(34)}$ や急縮小部におけるボイドの振動 や抗力低減法(35)(36) を実験的に調べたものがある.

マイクロチャネル内の二相流の研究には液体の微細 化 ${ }^{(37)}$ や酸化炭素などの排気ガスの吸収 ${ }^{(38)(39)}$ を目的 としたものがあり, マイクロバブルの研究には抗力低 減現象の解明(40)(41) を目的としたものがある.
気液二相流の数值解析に用いられる二流体モデルや ドリフトフラックスモデルの改良に資するための研究 も多く見られた。レーザフォーカス変位計を用いたマ イクロチャネル内の液膜計測(42) と通常口径管内の環 状流の液膜構造の計測(43)(44), 液膜界面積濃度の軸方 向発達特性(45)を調べた研究が行われた.さらには, 狭あい流路における気液界面波特性に及ぼす流路姿勢 の影響(46) や $5 \mathrm{~mm}$ 管内垂直上昇環状流において流動 障害物が液滴の液膜への付着に及ぼす影響(47)を調べ た研究, 流動様式遷移のモデル化にかかわる研究(48), 微小重力下を対象とするドリフトフラックスモデルの 開発研究(49) も行われた.

気液二相流の数值解析は非常に進歩しており, 気液 界面における局所的現象や多次元的挙動の計算が行わ れるようになってきている，すなわち，液体金属中の 微細気泡群が収縮によって圧力波の伝ぱを減衰する過 程を解いたもの ${ }^{(50)}$, 三次元 One-way 気泡追跡法によ って垂直円管内の未発達の気泡流とスラグ流を解いた もの ${ }^{(51)(52)}$, 格子ボルツマン法によって水平矩形流路 内の層状流の界面成長を解いたもの ${ }^{(53)}$, Phase-field モデルに基づく新たな計算法によって気泡内の圧力上 昇や静止した気体中や液膜上への単一液滴の落下過程 を解いたものがある(54)(55).

\section{4. 気液の混合系}

本展望では, プール沸騰や貯水槽内のエアレーショ ンのような片方の相のみが流動する系を気液の混合系 と称している.この系については, 2004 年 1 月〜2006 年 8 月までの日本機械学会発行の論文集に 35 件の研 究が発表された.ここでは, それらのなかで最近増え ている研究について触れる。

静止液中のさまざまな条件下における単一気泡の挙 動を扱った実験や数值解析が 7 件 [例えば, 文献 (56) ], 同じく二つの気泡の相互干渉を扱ったものが 5 件 [例えば, 文献(57)], 気泡の生成過程を扱ったもの が 3 件あった [例えば, 文献(58)].これらは, 気泡が 群として液とともに流動する気泡流の流動現象の解明 に資するためのものと思われる。

波立った水面 [例えば, 文献(59)］あるいは静止液 中に発生したマイクロバブル(60) から二酸化炭素, 二 酸化窒素や空気を水(海水を含む)に溶解させる研究も 6 件あった。 これらは地球温暖化物質の水中溶解によ る大気中の濃度低下, あるいは酸素を水中に供給して 好気性バクテリアを活性化させ水質浄化, に役立てよ うとする研究であり, 今後も盛んに行われると思われ る.また, マイクロバブル等の微細気泡の生成過程・ 
発生法・抗力低減作用に関する研究も 4 件あった [例 えば, 文献(61)]。マイクロバブル技術は, 上述の水質 浄化のほか洗浄, 化学反応促進, 超音波造影法などの 医療分野への応用が実用化されつつあり ${ }^{(62)}$ ，それぞれ の作用を説明しうるメカニズムの学術的な解明は十分 とはいえないものもあるが, 新たな応用分野の開拓を 目指した研究者や技術者は年々加速的に増えている。 したがって，マイクロバブル技術にかかわる研究もま すます盛んになると予想される。

なお，上記の引用文献以外にも優れた論文は多数あ ったが引用文件数が多くなりすぎるので割愛させてい ただいた。他意はないのでご容赦願いたい。

\section{5. おわりに}

2004 年 1 月〜 2006 年 8 月までに,「日本機械学会論 文集 B 編」と「JSME International Journal, Series II」に発表された気液二相流動系に関する 55 報を中 心として研究のレビューを行い, 併せて気液の混合系 に関する 35 報の研究動向にも触れ, 両分野での今後 の研究課題を探った. その結果, 現在までの $2 \sim 3$ 年 間はコンパクトやマイクロをキーワードとする実験的 研究や気泡の挙動に関する解析的研究が盛んであった ことがわかり，それらにかかわる研究は今後も当分は 続けられるように感ぜられた。本展望は, 気液二相流 にかかわる研究者・技術者が今後の研究課題を考えら れる際の参考になれば幸いである.

\section{文献}

(1) Mori, S. et al., On the Occurrence of Burnout Downstream of a Flow Obstacle in Boiling Two-Phase Upward Flow within a Vertical Annular Channel, Transactions of Japan Society of Mechanical Engineers, Series B, Vol. 70, No. 689 (2004), pp. 159-167.

(2) Hata, K. et al., Critical Heat Flux of Subcooled Water Flow Boiling against Inlet Subcooling in Short Vertical Tube, JSME International Journal, Series B, Vol. 47, No. 2 (2004), pp. 306-315.

(3) Okano, Y. et al., Countercurrent Gas-Liquid Flow and Heat Transfer Characteristics in Narrow Gap with Closed Bottom, Transactions of Japan. Society of Mechanical Engineers, Series B, Vol.71, No.702 (2005), pp. 610-616.

(4) Utaka, Y. et al., Behaviors of Micro-Layer in Microchannel Boiling System Applying Laser Extinction Method, Transactions of Japan Society of Mechanical Engineers, Series B, Vol. 71, No. 704 (2005), pp. 11331139.

(5) Tasaki, Y. and Utaka, Y., Effect of Surface Properties on Boiling Heat Transfer Characteristics in MicroChannel Vapor Generator, Transactions of Japan Society of Mechanical Engineers, Series B, Vol. 70, No. 691 (2004), pp. 737-743

(6) Hashizume, K. and Yuki, T., Flow Boiling Heat Trans- fer of Tap Water in Micro-Channels (2nd Report, Heat Transfer Correlation for Boiling Region in Straight Channels), Transactions of Japan Society of Mechanical Engineers, Series B, Vol.71, No.711 (2005), pp. 2823-2826.

( 7 ) Lim, T. W. and Kim, J. H., An Experimental Investigation of Pressure Drop in Flow Boiling of Pure Refrigerants and Their Mixture in Horizontal Tube, JSME International Journal, Series B, Vol. 48, No. 1 (2005), pp. 92-98.

(8) Hamada, H. et al., Two-Phase Flow Characteristics of Hot Water Discharged from a Thin Nozzle (2nd Report, Flow Characteristics of Self-Evaporating Two-Phase Free Jet), Transactions of Japan Society of Mechanical Engineers, Series B, Vol.70, No. 690 (2004), pp. 332-339.

(9) Ishimoto, J. and Kamijo, K., Numerical Study of TwoPhase Flow of Liquid Helium in Vertical ConvergingDiverging Nozzle, Transactions of Japan Society of Mechanical Engineers, Series B, Vol.70, No. 696 (2004), pp. 2134-2141.

(10) Fujii, T. et al., A Study of Dynamic Characteristics of the Thermal Control Systems Utilizing Latent Heat, Transactions of Japan Society of Mechanical Engineers, Series B, Vol. 70, No. 690 (2004), pp. 425-431.

(11) Fujii, T. et al., A Comparison between Analytical and Experimental Results in the Thermal Control System Utilizing Latent Heat, Transactions of Japan Society of Mechanical Engineers, Series B, Vol. 70, No. 699 (2004), pp. 2928-2934.

(12) Asano, H. et al., A Study of the Flow Characteristics of Gas-Liquid Two-Phase Flow in a Plate Heat Exchanger (Visualization and Void Fraction Measurement in a Single Channel), Transactions of Japan Society of Mechanical Engineers, Series B, Vol. 70, No. 700 (2004), pp. 3136-3140.

(13) Gima, S. et al., An Experimental Study on Cooling of CPU Using a Two Phase Cooled Thermosyphon Loop, Transactions of Japan Society of Mechanical Engi neers, Series B, Vol. 70, No. 694 (2004), pp. 1504-1509.

(14) Koito, Y. et al., Development of a Top-heat-type Heat Transport Loop Utilizing Vapor Pressure (Fundamental Experiments on Heat Transport Characteristics), Transactions of Japan Society of Mechanical Engineers, Series B, Vol. 72, No. 718 (2006), pp. 1574-1581.

(15) Akiba, M. et al., Prediction Method of Critical Power by Film Flow Rate Measurement and Subchannel Analysis, Transactions of Japan Society of Mechanical Engineers, Series B, Vol. 70, No. 695 (2004), pp. 17691776.

(16) Yamamoto, Y. et al., Critical Power Performance of Tight Lattice Bundle, JSME International Journal, Series B, Vol. 47, No. 2 (2004), pp. 344-350.

(17) Yamamoto, Y. et al., Thermal Performance of Tight Lattice Bundle, JSME International Journal, Series B, Vol. 49, No. 2 (2006), pp. 334-342.

(18) Morooka, S. et al., Study for Pressure Drop of Rod Bundle with Tight Lattice Array, Transactions of Japan Society of Mechanical Engineers, Series B, Vol. 72, No. 715 (2006), pp. 701-708.

(19) Tamai, H. et al., Pressure Drop Characteristics in Tight-Lattice Bundles for Reduced-Moderation Water Ractors, JSME International Journal, Series B, Vol. 47, No. 2 (2004), pp. 293-298.

(20) Takase, K. et al., Numerical Analysis of a Water- 
Vapor Two-Phase Film Flow in a Narrow Channel with a Three-Dimensional Rectangular Rib, JSME International Journal, Series B, Vol. 47, No. 2 (2004), pp. 323-331.

(21) Kawahara, A. et al., Single-- and Two-Phase Turbulent Mixing Rate between Subchannels in Triangle Tight Lattice Rod Bundle, JSME International Journal, Series B, Vol. 49, No. 2 (2006), pp. 287-295.

(22) Sadatomi, M. et al., Void Fraction and Pressure Drop in Two-Phase Equilibrium Flows in a Vertical $2 \times 3$ Rod Bundle Channel -Assessment of Correlations against the Present Subchannel Data, JSME International Journal, Series B, Vol. 49, No. 2 (2006), pp. 279286.

(23) Iwaki, C. et al., Characteristics of Bubbly Cross-Flow over Tube Bundles, Transactions of Japan Society of Mechanical Engineers, Series B, Vol.72, No.718 (2006), pp. 1543-1550.

(24) Tominaga, A. et al., Effects of the Inner Diameter of a Ring-Type Obstacle on Liquid Film Thickness in Upward Gas-Liquid Two-Phase Flow in a Vertical Tube, Transactions of Japan Society of Mechanical Engineers, Series B, Vol. 70, No. 689 (2004), pp. 77-84.

(25) Tominaga, A. et al., Effects of the Opening Area Ratio of a Ring-Type Obstacle on Liquid Film Thickness in Upward Gas-Liquid Two-Phase Flow in a Vertical Tube, Transactions of Japan Society of Mechanical Engineers, Series B, Vol.70, No.692 (2004), pp. 871879.

(26) Nishi, Y. et al., Experimental Study on the Gas Lift Pump in Lead-Bismuth Eutectic, Transactions of Japan Society of Mechanical Engineers, Series B, Vol. 70, No. 691 (2004), pp. 715-722.

(27) Yamazaki, Y. et al., Studies on Mixing Process and Performance Improvement of Jet Pump (Effects of Nozzle and Throat Shapes), Transactions of Japan Society of Mechanical Engineers, Series B, Vol.71, No. 701 (2005), pp. 147-153.

(28) Yamazaki, Y. et al., Effect of Throat Surface Roughness on Jet Pump Performance, Transactions of Japan Society of Mechanical Engineers, Series B, Vol. 72 , No. 720 (2006), pp. 1895-1900.

(29) Furukawa, A. et al., Development of Air-Water TwoPhase Flow Centrifugal Pump and Its Operating Characteristics, Transactions of Japan Society of Mechanical Engineers, Series B, Vol.71, No.701 (2005), pp. 140-146.

(30) Furukawa, A. et al., Air/Water Two-Phase Flow Performance of Contra-Rotating Axial Flow Pump and Rotational Speed Control of Rear Rotor, Transactions of Japan Society of Mechanical Engineers, Series B, Vol. 71, No. 708 (2005), pp. 2047-2052.

(31) Yoneda, K. and Inada, F., Flow Characteristics of Centrifugal Gas-Liquid Separator (Investigation with Air-Water Two-Phase Flow Experiment), Transactions of Japan Society of Mechanical Engineers, Series B, Vol. 70, No. 690 (2004), pp. 363-370.

(32) Ishiguro, K. et al., Separation of Gas from Downward Gas-Liquid Two-Phase Flow Using a Y-Junction of Poor Wettability, JSME International Journal, Series B, Vol. 47, No. 11 (2004), pp. 795-803.

(33) Kondo, K. et al., Void Fraction Distribution of Upward Bubbly Flow in a Vertical Pipe with Sudden Expansion, Transactions of Japan Society of Mechanical Engineers, Series B, Vol.71, No.703 (2005), pp. 796-
803.

(34) Kondo, K. et al., Flow Regimes of Upward Gas-Liquid Two-Phase Flow in a Vertical Pipe with an Axisymmetric Sudden Expansion, Transactions of Japan Society of Mechanical Engineers, Series B, Vol. 71, No. 711 (2005), pp. 2679-2685.

(35) Voutsinas, A. et al., Gas-Liquid Two-Phase Oscillating, Fluctuating Flow through Vertical Sudden Contraction, Transactions of Japan Society of Mechanical Engineers, Series B, Vol. 72, No. 717 (2006), pp. 11311136.

(36) Voutsinas, A. et al., Flow Characteristics and Drag Reduction of Vertical Upward Gas-Liquid Two-Phase Flow through Sudden Contraction Pipe, Transactions of Japan Society of Mechanical Engineers, Series B, Vol. 72, No. 720 (2006), pp. 1888-1894.

(37) Shintaku, H. et al., Development of Atomization Method in Microchannel and Its Basic Characteristics, Transactions of Japan Society of Mechanical Engineers, Series B, Vol. 71, No. 708 (2005), pp. 2007-2012.

(38) Nakabeppu, O. and Deno, K., Gas Absorption of Slug Flow in Microchannel (1st Report, Experimental Study with $\mathrm{CO}_{2} /$ Water System), Transactions of Japan Society of Mechanical Engineers, Series B, Vol.70, No. 693 (2004), pp. 1285-1292.

(39) Ito, Y. et al., Mass Transfer through Gas-Liquid Interface in a Micro Channel, Transactions of Japan Society of Mechanical Engineers, Series B, Vol.72, No. 715 (2006), pp. 584-588.

(40) Kitagawa, A. et al., Combined Particle Image Velocimetry of Turbulence Modification in a $\mathrm{Mi}$ crobubble Channel Flow, Transactions of Japan Society of Mechanical Engineers, Series B, Vol.71, No.701 (2005), pp. 44-51.

(41) Oishi, Y. et al., Skin Friction Drag in a Horizontal Turbulent Channel Flow Containing Bubbles (Synchronized Measurement of Gas-Liquid Interface Behavior and Local Wall Shear Stress), Transactions of Japan Society of Mechanical Engineers, Series B, Vol. 71, No. 706 (2005), pp. 1542-1549.

(42) Hazuku, T. et al., Measurement of Interfacial Displacement of a Liquid Film in Microchannel Using Laser Focus Displacement Meter, Transactions of Japan Society of Mechanical Engineers, Series B, Vol. 70, No. 694 (2004), pp. 1481-1488.

(43) Hazuku, T. et al., Measurement of Interfacial Structure on Liquid Film in Annular Flow Using Laser Focus Displacement Meter (1st Report, Measurement Accuracy and Axial Development of Liquid Film), Transactions of Japan Society of Mechanical Engineers, Series B, Vol. 71, No. 705 (2005), pp. 1265-1271.

(44) Hazuku, T. et al., Measurement of Interfacial Structure on Liquid Film in Annular Flow Using Laser Focus Displacement Meter (2nd Report, Disturbance Wave Frequency and Local Minimum Film Thickness), Transactions of Japan Society of Mechanical Engineers, Series B, Vol. 71, No. 705 (2005), pp. 12721277.

(45) Hazuku, T. et al., Axial Development of Interfacial Area Concentration of Liquid Film in Vertical Upward Annular Two-phase Flow, Transactions of Japan Society of Mechanical Engineers, Series B, Vol. 72, No. 717 (2006), pp. 1189-1195.

(46) Swai, T. et al., Effect of Flow Orientation on Characteristics of Gas-Liquid Interfacial Waves in Narrow 
Rectangular Channel, Transactions of Japan Society of Mechanical Engineers, Series B, Vol.71, No.710 (2005), pp. 2427-2433.

(47) Okawa, T. et al., An Experimental Study on the Mass Transfer Rate of Droplets in Annular Two-Phase Flow, JSME International Journal, Series B, Vol. 49, No. 2 (2006), pp. 271-278.

(48) Ito, K. et al., A Simplified Model of Gas-Liquid TwoPhase Flow Pattern Transition, Transactions of Japan Society of Mechanical Engineers, Series B, Vol.70, No. 689 (2004), pp. 151-158.

(49) Hibiki, T. et al., Development of Drift-Flux Model at Microgravity Conditions, Transactions of Japan Soci. ety of Mechanical Engineers, Series B, Vol. 70, No. 696 (2004), pp. 2043-2050.

(50) Okita, K. et al., Propagation of Pressure Waves, Caused by a Thermal Shock, in Liquid Metals Containing Gas Bubbles, Transactions of Japan Society of Mechanical Engineers, Series B, Vol.72, No.716 (2006), pp. 885-892.

(51) Tamai, H. and Tomiyama, A., Three-Dimensional One-Way Bubble Tracking Method for the Prediction of Developing Bubble-Slug Flows in a Vertical Pipe (1st Report, Models and Demonstration), Transactions of Japan Society of Mechanical Engineers, Series B, Vol. 70, No. 692 (2004), pp. 880-887.

(52) Tamai, H. and Tomiyama, A., Three-Dimensional One-Way Bubble Tracking Method for the Prediction of Developing Bubble-Slug Flows in a Vertical Pipe (2nd Report, Comparisons between Experiments and Calculations), Transactions of Japan Society of Mechanical Engineers, Series B, Vol.70, No. 692 (2004), pp. 888-895.

(53) Ebihara, K. and Watanabe, T., Evaluation of Influence of Pipe Width on Interfacial Growth of Horizontal Stratified Two-Phase Flow in Rectangular Pipe by Lattice Boltzmann Method, Transactions of Japan Society of Mechanical Engineers, Series B, Vol. 70, No. 694 (2004), pp. 1393-1399.
(54) Takada, N. and Tomiyama, A., A Numerical Method for Two-Phase Flow Based on a Phase-Field Model, Transactions of Japan Society of Mechanical Engi. neers, Series B, Vol. 71, No. 701 (2005), pp. 117-123.

(55) Takada, N. and Tomiyama, A., A Numerical Method for Two-Phase Flow Based on a Phase-Field Model, JSME International Journal, Series B, Vol.49, No. 3 (2006), pp. 636-644.

(56) Takahira, H. et al., Numerical Simulations of Bubble Growth and Detachment in Microgravity and Normal Gravity Shear Flows, Transactions of Japan Society of Mechanical Engineers, Series B, Vol.71, No.705 (2005), pp. 1256-1264.

(57) Sanada, A. et al., Bouncing and Coalescence of a Bubble Approaching to Free Surface, Transactions of Japan Society of Mechanical Engineers, Series B, Vol. 70, No. 692 (2004), pp. 863-870.

(58) Tange, M. and Shoji, M., Bubbling from Submerged Twin-Orifices and a Simplified Model, Transactions of Japan Society of Mechanical Engineers, Series B, Vol. 70 , No. 690 (2004), pp. 348-355.

(59) Tanno, K. and Komori, S., Effects of Swell on Turbulence Structure and Mass Transfer Across the WindDriven Air-Water Interface, Transactions of Japan Society of Mechanical Engineers, Series B, Vol.70, No. 691 (2004), pp. 644-648.

(60) Yamada, S. et al., A Study for Distribution of Mirobubbles and Effects of Oxygen Supplying into Water, Transactions of Japan Society of Mechanical Engineers, Series B, Vol. 71, No. 705 (2005), pp. 1301-1306.

(61) Makuta, T. et al., Generation of Micro Gas Bubbles of Uniform Diameter in an Ultrasonic Field (1st Report, Effect of Viscosity on Stable Generation of Bubbles of Uniform Diameter), Transactions of Japan Society of Mechanical Engineers, Series B, Vol.70, No. 699 (2004), pp. 2758-2767.

(62) Ueyama, T. and Miyamoto, M., World of Micro-bubbles-Cooperative Action of Water and Gas (in Japanese), (2006), Kougyoutyousakai, Tokyo. 